\title{
Construction and validation of a sleep hygiene booklet for the elderly
}

\author{
Construção e validação de cartilha para idoso acerca da higiene do sono \\ Construcción y validación de un manual para ancianos acerca de la higiene del sueño
}

\section{Khelyane Mesquita de Carvalho' ORCID: 0000-0003-4270-3890}

Maria do Livramento Fortes Figueiredo" ORCID: 0000-0003-4938-2807

Nelson Miguel Galindo Neto"'I ORCID: 0000-0002-7003-165X

\section{Guilherme Guarino de Moura Sá'} ORCID: 0000-0003-3283-2656

'Universidade Federal do Piauí. Bom Jesus, Piauí, Brazil.

"Universidade Federal do Piauí. Teresina, Piauí, Brazil. I'Instituto Federal de Pernambuco. Pesqueira, Pernambuco, Brazil.

How to cite this article: Carvalho KM, Figueiredo MLF, Galindo Neto NM, Sá GGM.

Construction and validation of a sleep hygiene booklet for the elderly. Rev Bras Enferm. 2019;72(Suppl 2):214-20. doi: http://dx.doi.org/10.1590/0034-7167-2018-0603

\section{Corresponding Author:}

Khelyane Mesquita de Carvalho E-mail: khelyanemc@gmail.com

Submission: 07-23-2018

Approval: 04-23-2019

\section{ABSTRACT}

Objective: to construct and validate an educational booklet for the elderly, with guidelines on sleep hygiene. Method: a methodological research with booklet construction; validation by 22 judges and evaluation by 22 elderly people. The content was extracted from the guidelines of the Brazilian Sleep Association and the elderly health manual of the Human Rights Office. The item with Content Validity Index (CVI) greater than 0.8 or whose concordance ratio verified with the Binomial Test was valid and statistically equal to or greater than $80 \%$. Results: the booklet presented 14 guidelines for the elderly about sleep hygiene distributed over 25 pages. All items were evaluated as relevant. The CVI had an average of 0.95 by the judges and 0.95 by the elderly. Conclusion: the booklet was constructed and validated as to its content and appearance. It can be used by health professionals in the various services with the elderly.

Descriptors: Validation Studies; Health of the Elderly; Sleep; Sleep Hygiene; Health Education.

\section{RESUMO}

Objetivo: construir e validar cartilha educativa para idosos, com orientações sobre higiene do sono. Método: pesquisa metodológica com construção da cartilha, validação por 22 juízes e avaliação por 22 idosos. O conteúdo foi extraído das orientações da associação brasileira do sono e do manual de saúde do idoso da Secretaria de Direitos Humanos. Foi considerado válido o item com Índice de Validade de Conteúdo (IVC) maior que 0,8 ou cuja proporção de concordância, verificada com o teste binomial, foi estatisticamente igual ou superior a $80 \%$. Resultados: a cartilha apresentou 14 orientações para idosos sobre higiene do sono, distribuídas em 25 páginas. Todos os itens foram avaliados como pertinentes e o IVC teve média de 0,95 pelos juízes e 0,95 pelos idosos. Conclusão: a cartilha foi construída e validada quanto seu conteúdo e aparência e pode ser utilizada pelos profissionais de saúde nos diversos serviços com o público idoso.

Descritores: Estudos de Validação; Saúde do Idoso; Sono; Higiene do Sono; Educação em Saúde.

\section{RESUMEN}

Objetivo: construir y validar un manual educativo para ancianos, con orientaciones sobre higiene del sueño. Método: investigación metodológica con construcción de lo manual, validación por 22 jueces y evaluación por 22 ancianos. El contenido fue extraído de las orientaciones de la asociación brasileña del sueño y del manual de salud del anciano de la Secretaría de Derechos Humanos. Se consideró válido el ítem con Índice de Validez de Contenido (IVC) mayor que 0,8 o cuya proporción de concordancia, verificada con el Test Binomial, fue estadísticamente igual o superior al $80 \%$. Resultados: lo manual presentó 14 orientaciones para ancianos sobre higiene del sueño, distribuidas en 25 páginas. Todos los ítems fueron evaluados como pertinentes y el IVC tuvo promedio de 0,95 por los jueces y 0,95 por los ancianos. Conclusión: lo manual fue construida y validada en cuanto a su contenido y apariencia, pudiendo ser utilizada por los profesionales de salud en los diversos servicios con el público anciano. Descriptores: Estudios de Validación; Salud del Anciano; Sueño; Higiene del Sueño; Educación en Salud. 


\section{INTRODUCTION}

Sleep is a transient and reversible state that alternates with the waking state and plays a relevant role in recovery of energy flow and physical and mental restoration ${ }^{(1)}$. Since sleep is recognized as part of a healthy lifestyle, impairment to its quality contributes to illness ${ }^{(2)}$.

The efficiency of sleep decreases in the elderly, which favors the increase of nocturnal awakenings and difficulty to fall asleep again ${ }^{(3)}$. This fact presents an expressive prevalence so that approximately $50 \%$ of people 60 years of age or older present with sleep disorder ${ }^{(4-5)}$.

The poor quality of sleep in the elderly population and the repercussions on health are pointed out in the scientific literature: results of research carried out in the United States showed the presence of dissatisfaction with sleep in $19.3 \%$ of the elderly, associated with poorer general health status and self-medication ${ }^{(6)}$. Another study showed association of sleep impairment with development of depression in the elderly in Singapore ${ }^{(7)}$, while a survey carried out with elderly people in Greece also showed that the poor quality of sleep reverberates in worse storage capacity ${ }^{(8)}$.

Among the strategies to promote sleep improvement, the performance of sleep therapy and hygiene, as observed in a systematic review, whose results show that although cognitive behavioral therapy presents high effectiveness, sleep hygiene was also able to produce improvement in sleep ${ }^{(9)}$.

Sleep hygiene is about changing behavior and suitability of the environment in order to favor improvement in sleep, without the need for medication. Conducts that integrate sleep hygiene include light feeding before bedtime, environment preparation (reduction of sound, visual and luminous stimuli) and established sleep routine ${ }^{(5)}$.

For the American Sleep Association, guidelines for the population about sleep quality are relevant, and health education interventions on the subject demand investment of the efforts of professionals involved in public health ${ }^{(10)}$.

In nursing, health education has used technological resources that favor the mediation of teaching and learning in care. Such technologies enable the dissemination of information, facilitate understanding and broaden the facets of formal education ${ }^{(11)}$.

The technologies used for health education vary from hypermedia and games, to those that are printed, such as albums, series and booklets. Specifically, about the technologies used in care for the elderly, results of literature review point out the use and effectiveness of the booklet as a technological option ${ }^{(12)}$.

Since impairment of sleep quality in the elderly affects health, sleep hygiene may contribute to improved sleep. Printed materials are relevant for elderly health education on various healthrelated topics. It is important to emphasize the importance of investment in the construction of printed material about sleep hygiene, aimed at the elderly, based on the guiding question: does the educational booklet built for the elderly, with guidelines on sleep hygiene, have content validity as evaluation of health professionals and understood by the elderly?

The construction and validation of educational technology, with a view to promoting sleep hygiene in the elderly, converge the National Policy for Older Persons (Política Nacional Saúde da Pessoa Idosa). This policy directs collective and individual health measures for the elderly population, in accordance with the legal principles of the Brazilian Unified Health System (Sistema Único de Saúde), in order to promote active and healthy aging ${ }^{(13)}$. Moreover, the construction of such material is relevant for geriatrics and gerontology, because it provides educational technology that can be used by professionals or the elderly, autonomously.

\section{OBJECTIVE}

To construct and validate an educational booklet for the elderly, with guidelines on sleep hygiene.

\section{METHOD}

\section{Ethical aspects}

The study complied with Resolution 466/12 and was approved by the Research Ethics Committee of the Universidade Federal do Piauí (Opinion 2,404,143).

\section{Design, place of study and period}

It is a methodological research, with a quantitative approach, with the construction and validation of content of a booklet focused on the education in the health of the elderly about sleep hygiene, carried out from December 2017 to February 2018, in the municipality of Bom Jesus - Piauí State.

\section{Population or sample; inclusion and exclusion crieria}

Validation of the content of the booklet was carried out through consultation with specialist nurses from the area of interest distributed into two distinct categories: researchers/professors in the health of the elderly and/or sleep field, as well as health care professionals in the elderly, selected by "snowball" sampling.

Although other professionals work in the health care of the elderly, nurses were consulted in view of the high probability of these professionals having experience with the specificities of health education and educational materials for the elderly (since the role of educator is inherent to the professional practice of nursing and that such professionals are responsible for the construction of subjects for health education), because they have a great chance of expertise about sleep disorders in the elderly and sleep hygiene (since this complaint a frequent occurrence in outpatient clinics/ geriatrics services and that sleep hygiene guidelines integrate the guidelines present in the nursing consultation to the elderly with impaired sleep quality) and by these professionals once inserted in the academic environment and in reference services, besides being very likely to be updated in relation to the subject.

In addition, although there are other professionals, such as doctors, biologists and psychologists, who could be specialists in sleep, these professional categories have expertise and dominate other aspects related to sleep (such as biochemical changes, drug effectiveness and psychotherapy) that are not a priority in the validation of the educational booklet, which deals specifically with sleep hygiene. Thus, it was considered pertinent that nursing professionals evaluate the content of the booklet and participate in its validation, because such professional category has expertise in the three relevant components to be evaluated/ 
validated: sleep hygiene, construction of educational materials and health education of the elderly.

The sample was calculated from the $n=Z a^{2} \cdot P(1-P) / e^{2}$ formula ${ }^{(14)}$. From this, it was obtained the value of 22 participants to integrate the body of judges, against the use of $95 \%$ for the confidence level $(\mathrm{Za}) ; 85 \%$ for the concordance ratio of the judges $(\mathrm{P}) ; 15 \%$ for the difference allowed (e). The criterion of inclusion was to have at least one year of experience (assistance or teaching/research) with the subject matter; and the exclusion criterion was the incomplete filling out of the data collection instrument used.

To evaluate the educational booklet by the target public, the number of invited elderly was calculated from the $n=Z a^{2} \cdot P(1-P) / e^{2}$ formula ${ }^{(14)}$. When using the following parameters: $Z a$ (confidence level) $=95 \% ; \mathrm{P}$ (agreement ratio) $=85 \%$; and (difference admitted) $=15 \%$, a total of 22 elderly were obtained to participate in the evaluation of the booklet. By simple random sampling, 22 elderly enrolled in the Family Health Strategy were selected to evaluate the material. Nurses from the Family Health Teams were obtained from the three Basic Health Units with the highest demand for elderly people in the municipality of Bom Jesus - PI, lists with the names of the elderly registered. These lists were synthesized into a single list, which was arranged in alphabetical order, and the names were listed in ascending order. Thus, 22 numbers were chosen that corresponded to the respective names of the list.

When considering that the criterion of inclusion of the target audience was restricted to being literate and the criterion of exclusion was to have visual impairment or pathology that made the evaluation of the booklet unfeasible, the Community Health Agents responsible for the micro areas in which the elderly people who were drawn up resided were consulted in order to verify literacy and the presence of disability or pathology in the elderly. In addition, in the respective Basic Health Units, there was access to and consultation of the medical records of the elderly, in order to triangulate the information obtained. In cases in which the elderly did not have an eligible profile for participation, a new lottery was carried out until the sample size was reached.

\section{Study protocol}

The content to compose the booklet was obtained through the guidelines of the Brazilian Sleep Association and the elderly health manual ${ }^{(5,15)}$. In order to make the material closer to the reality and the need of the target audience, we considered the experience and prior knowledge about sleep obtained from a focus group with elderly people assisted by Primary Health Care in the city of Bom Jesus, Piauí State. In such a survey, the elderly voiced difficulties to sleep well and were unaware of the factors and behaviors that may interfere with sleep quality.

With the help of graphic designer, the art was elaborated by means of the creation of figures by vectorization and the refinement of the same ones in the program Corel Draw X7, with respect to the formatting, configuration and diagramming of the pages. It is important to emphasize that specific guidelines regarding the structure, text and layout of the booklet followed the one recommended for text of educational technologies ${ }^{(16)}$.

The educational material content was organized according to the theoretical framework of the health belief model, which includes factors that influence the health behavior of the population. The five factors contemplated by the health belief model are the perception that it is susceptible to some health risk situation (contemplated in the booklet with content about the susceptibility of the elderly to the impairment of sleep quality); the perception for the severity of such a situation (addressed in the booklet by content relating to harmful consequences to health, arising from impairment in sleep); the perception of the benefits of performing actions that reduce the risk (contemplated in the booklet regarding content about the benefits of behaviors that improve the quality of sleep, which are the items of sleep hygiene); the perception for the barriers about the accomplishment of such actions (addressed in the booklet in content that pointed out possible barriers and difficulties to perform the hygiene of sleep); and self-confidence to perform actions (corroborated in the booklet by the presence of statements that reinforce the elderly's ability to practice the guidelines for sleep hygiene) ${ }^{(17)}$.

Content validation was carried out after completing the booklet's construction. The electronic form that contained the Informed Consent Form (in which there were options of agreement or disagreement to participate in the study, where only one of them could be indicated by the professional), the PDF booklet and the data collection instrument were sent to the e-mail of elderly health area professors, undergraduate courses in nursing of public (federal and state) universities in Piauí State.

When considering that snowball type sampling was used, a request was made to the said professors, in the same e-mail in which the form was sent, to indicate other professionals with profile eligible for participation in the study. Therefore, names and e-mail addresses were obtained from other elderly health professors of nursing courses, from federal and state public institutions, from the states of Pernambuco, Ceará, Paraíba and São Paulo. Furthermore, there was the sending to the electronic address of nurses working in geriatric care services, from the same states, obtained from telephone contact with such institutions. After sending e-mail to 52 professionals, the sample was composed of 22 who submitted the completed form and registered their agreement to participate in the study by signing the Free and Informed Consent Form.

For this stage, the Educational Content Validation Instrument (ECVI) was used/e-mailed to professionals ${ }^{(18)}$. This instrument, constructed and validated by a research group of the Universidade Federal do Ceará, contains 18 questions (about the objective, structure, presentation and relevance) that, on a Likert scale, have options to be indicated that vary from total disagreement to total agreement.

It was observed that the only adjustments suggested by professionals were about reformulation of text in some sentences, so that they became more comprehensible. Accordingly, such modifications, as suggested by the judges, were duly done.

After completion of the construction, the booklet was evaluated by the target audience. This stage occurred in the three Basic Health Units that presented the highest demand of the elderly, in the municipality of Bom Jesus. Participants (elderly), drawn from a list provided by the nurses of the health units, were captured/ approached from home visits conducted by the researcher, accompanied by the Community Health Agents responsible for the respective micro-areas of residence of the elderly.

On a single visit, each elderly person was guided in relation to the objective and their participation in the study, signed the 
FICF, received a printed copy of the booklet and carried out their reading without interferences of the researcher. When verbalizing the completion of the reading of the educational material, the instrument was given to the elderly to evaluate the booklet. The instrument was adapted from the Suitability Assessment of Materials (SAM), with 19 questions (referring to the understanding of the material) and space for suggestions ${ }^{(19)}$.

After evaluation of the booklet by the elderly, the only suggestion obtained and performed was the increase in the text size proposed by one of the elderly.

\section{Analysis of results and statistics}

The data analysis was performed using the software $\mathrm{R}$, version 3.1.1, from the Content Validation Index, calculated in its three forms: Item-Level Content Validity Index (I-CVI), which is the agreement of the evaluators for each item; Scale-Level Content Validity Index, Average Calculation Method (S-CVI/AVE), which is the proportion of items that each evaluator agreed to and the Scale-Level Content Validity Index (S-CVI), which is a result of the sum of the S-CVI, divided by the number of evaluators. The minimum proportion of agreement for which the item was considered valid was $80 \%^{(20)}$. The Binomial Test was used, with significance level of $5 \%$, to verify, in a statistical way, whether the agreement was equal to or greater than $80 \%$.

\section{RESULTS}

The booklet was entitled "Durma bem e viva melhor" (Sleep well and live better) and was composed of 25 pages, with cover, back cover, datasheet, cover sheet, summary, cover page, references and note sheets.

The booklet content was presented in the following sequence: according to the first stage of the health belief model, the booklet initially contains questions (as "Are you satisfied with your sleep?"; "Does it take long to get to sleep?"; “Do you sleep all night?") for reader's reflection about the susceptibility to sleep quality impairment. Then, in corroboration with the second stage of the referential (perceived severity), the booklet presented the physical and physiological consequences, such as fatigue, weakness, irritability, risk for elevated blood pressure, weight gain, caused by poor sleep quality. Subsequently, the presentation of 14 sleep hygiene guidelines (referring to the preparation of the body and the environment for sleep, the correct diet near the bedtime and the established routine at night and to sleep, with the necessary justifications of the relevance of its realization, which dealt with the third and fourth stage of the theoretical reference (benefits and perceived barriers). The content was finalized with encouraging phrases such as"It is possible to sleep better, doing simple things that only depend on you" and "Durma bem e viva melhor" (Sleep well and live better), in order to boost the reader's self-confidence to perform the actions described in the sleep hygiene guidelines, in accordance with the fifth stage of the theoretical reference (self-confidence to perform actions). Some pages of the booklet are shown in Figure 1.

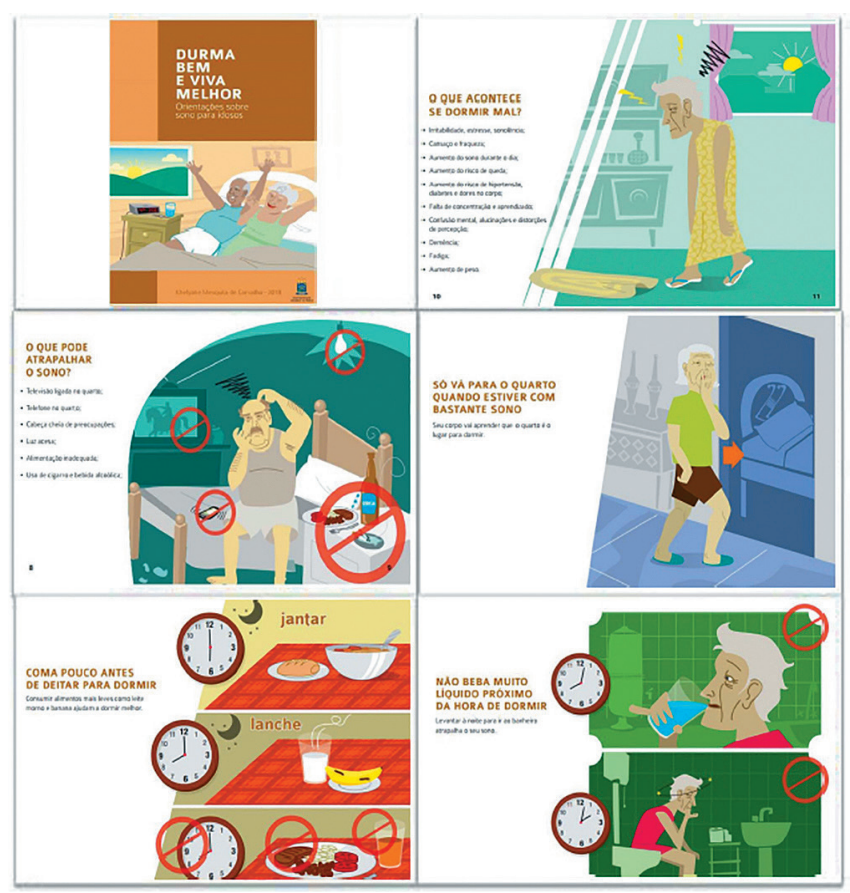

Figure 1 - Some pages of the educational booklet "Durma bem e viva melhor" (Sleep well and live better), Teresina, Piauí, Brazil, 2018

Table 1 - Judges' agreement with the objective, structure, presentation, size and relevance of the booklet, Teresina, Piauí, Brazil, 2018

\begin{tabular}{|c|c|c|c|c|}
\hline Item & $\begin{array}{c}\text { I totally agree } \\
\text { n (\%) }\end{array}$ & $\begin{array}{c}\text { I agree } \\
n(\%)\end{array}$ & $\mathrm{I}-\mathrm{CV} \mathbf{I}^{*}$ & $\begin{array}{c}p \\
\text { value*** }\end{array}$ \\
\hline
\end{tabular}

1. Objectives and purposes

1.1 Address the proposed theme

1.2 Adequate to teaching-learning

1.3 Clarifies doubts

1.4 Provides reflection

1.5 Encourages behavior change

2.1 Language suitable for the target audience

2.2 Language suitable for the educational material

2.3 Interactive language

2.4 Correct information

2.5 Objective information

2.6 Clarifyng information

2.7 Necessary information

2.8 Logical sequence of ideas

2.9 Current theme

2.10 Appropriate text size

3. Relevance, significance, impact, motivation and interest

3.1 Encourages learning

3.2 Contributes to the knowledge in the area

3.3 Awakens interest in the subject
2. Structure. presentation and organization

$\begin{array}{cccc}18(81.8) & 4(18.2) & 1 & 1 \\ 14(63.6) & 8(36.4) & 1 & 1 \\ 14(63.6) & 8(36.4) & 1 & 1 \\ 17(77.3) & 5(22.7) & 1 & 1 \\ 18(81.8) & 4(18.2) & 1 & 1 \\ & & & \\ 12(54.5) & 10(45.5) & 1 & 1 \\ 15(68.2) & 7(31.8) & 1 & 1 \\ 16(72.7) & 6(27.3) & 1 & 1 \\ 17(77.3) & 5(22.7) & 1 & 1 \\ 19(86.4) & 3(13.6) & 1 & 1 \\ 15(68.1) & 7(31.8) & 1 & 1 \\ 19(86.4) & 3(13.6) & 1 & 1 \\ 17(77.3) & 4(18.2) & 0.95 & 0.97 \\ 22(100) & 0(0.0) & 1 & 1 \\ 14(63.6) & 8(36.4) & 1 & 1 \\ & & & \\ 19(86.4) & 3(13.6) & 1 & 1 \\ 19(86.4) & 3(13.6) & 1 & 1 \\ 19(86.4) & 3(13.6) & 1 & 1\end{array}$

Note: *Item-Level Content Validity Index; **Binomial Test. 
Content validation was performed by 22 judges, nurses, of whom 20 had teaching experience and had already taught courses in the health area of the elderly. In relation to the degree, 11 were doctors in nursing and 11 were masters. With regard to scientific production, 18 had already published an article in journals about elderly health. Five have expertise in "sleep" theme.

Of the 18 items evaluated in content validation, 17 had unanimous agreement $(\mathrm{I}-\mathrm{CVI}=1.0)$. There was agreement of all judges on relevant items, such as the adequacy of the booklet to teachinglearning, the information being correct and the text size adequate, as shown in Table 1.

Of the 22 judges, 21 agreed on all items, so the S-CVI/AVE of these was 1.0. The remaining judge disagreed with only one item (SCVI/AVE=0.94), so S-CVI (mean SCVI/AVE) was 0.99.

Of the elderly who evaluated the booklet, $68.2 \%$ were women, 16 had completed elementary school, four had completed high school and two had completed higher education.

The concordance index of the evaluation of the elderly was from 1.0 to 17 items. In only one item in the Layout category (referring to letter size and font), the I-CVI was 0.95, since there was discordance by an elderly person. There was unanimity about the text being comprehensive, having a logical sequence, formulated in an attractive way, compatible with the understanding, clearly and objectively. Furthermore, the elderly judged that the illustrations helped to understand the content.

\section{DISCUSSION}

Information multiplication made possible by educational material about sleep hygiene is relevant to address the popular belief that the most effective way to improve sleep quality is through pharmacological intervention. Simple and low-cost procedures have been shown to be effective, as observed in a study carried out in the Netherlands, in which the results showed that the preparation of the sleeping environment, contemplated in the sleep hygiene guidelines, such as opening doors and windows in the bedroom to improve ventilation, improved sleep duration and depth ${ }^{(21)}$. In this way, the relevance and the need to inform the population about such content are highlighted, and they are covered by the booklet.

Individualized educational intervention effectiveness on self-care for sleep is demonstrated in a randomized clinical trial conducted in Sweden ${ }^{(22)}$, as well as found in a systematic review on the efficacy of non-drug interventions for sleep improvement, which indicates that educational strategies have been used successfully ${ }^{(23)}$. In this perspective, the relevance of the existence of an educative resource, constructed and validated, that can be used in health education about sleep.

Educational book construction corroborates the National Policy for Older Persons (Política Nacional Saúde da Pessoa Idosa) because it contributes to the independence and autonomy of the elderly, referring to the behaviors adopted for sleep hygiene. Furthermore, the booklet converges with comprehensiveness in care, inherent in the practice of nursing and with the health care model whose center is the user ${ }^{(24)}$.

Regarding the evaluation of the booklet, the images were considered clear, comprehensive and enlightening by the elderly who judged it, who considered that there was no need to adjust them. About the evaluation of images in validation studies, in methodological research in Malaysia, in which educational booklet on eating practices was validated, the target public was consulted. Although they considered the images of the material comprehensible, they suggested expanding their size ${ }^{(25)}$. On the other hand, the result of a Brazilian study of validation of a booklet for relatives of neonates in neonatal intensive care unit, showed that the images were considered didactic, correct and sufficient by the evaluators ${ }^{(26)}$.

In view of the importance of the images for understanding educational materials, it is necessary to investigate the level of understanding of the illustrations, as well as possible suggestions that may contribute to the improvement of the quality presented. Within the present context, it is highlighted the relevance of the booklet to have illustrations that depict sleep hygiene guidelines. Thus, the possibility of its use in educational interventions carried out with the non-literate elderly public is widened, for although other sources of information, such as booklets and health manuals, address sleep hygiene, they do so only in the form of text and become not understandable and ineffective for the information of individuals who do not read.

In addition to the evaluation of the images, there was agreement of the elderly about the written content of the booklet if it is clear and in language compatible with their understanding. This finding corroborates a Brazilian study that validated a booklet for prevention of vertical transmission, in which the target audience agreed on the clarity of the information presented by the material ${ }^{(27)}$. Nonetheless, such Brazilian findings are in contrast to research carried out in Africa, whose results indicate that $75 \%$ of the target audience could not understand written content on schistosomiasis ${ }^{(28)}$. The discrepancy in the results obtained in the studies points to the need to consult the target public about the clarity/comprehension of educational materials, especially those related to health issues, in which misinterpretation or unfeasibility may impact prevention, promotion and health recovery.

Regarding the agreement of judges, there was unanimity regarding the booklet being appropriate to teaching-learning, with correct information and adequate size. Similar findings were found in other studies (on the construction and validation of a booklet for teaching first aid at school and a booklet for HIV prevention in the elderly) ${ }^{(29-30)}$.

Appropriateness of proper educational materials and sizes must be considered in validation processes so that the final material provided is not short enough to compromise the quality of the information and not long enough to become tiring for the reader. Furthermore, the verification of the information is correct so that it is not disseminated misleading and/or outdated information that in health can be a risk to the reader.

The changes suggested by the judges concerned the reformulation of some sentences. Such suggestion of adjustments was also found in a study that validated an educational booklet to promote maternal self-efficacy in the prevention of childhood diarrhea ${ }^{(31)}$. Textual adjustments suggested by the evaluators in the construction and validation educational booklets are relevant to be carried out and contribute to the booklet being judged as understandable and clear when evaluated by the target audience. Such a judgment is 
very important for the final product because even if an educational technology has correct content and not understandable to the target audience, it will have its use unfeasible, which is a waste of all efforts and intellectual and material investments.

\section{Study limitations}

The limitations of this study are that the printed material specifically addresses sleep hygiene and does not address other aspects that may contribute to improved sleep quality such as psychotherapy, physical activity and pharmacological interventions. However, content excess could make the educational material extensive and tiring, in addition to having scientific support about the effectiveness of sleep hygiene to improve sleep quality. Moreover, the study had as a limitation the fact that the evaluation of the material occurred with representatives of the target audience users of Primary Health Care services so that their findings may not include the opinion of elderly users of the private healthcare network about the booklet.

\section{Contributions to the Nursing, Health or Public Policy}

The constructed and validated booklet can contribute to the dissemination of information on sleep hygiene, be used by nurses and other health professionals in educational interventions and thus reflect on the improvement of sleep quality of the elderly. In addition, there is the possibility and potential to contribute to the translation of knowledge, since it is a self-explanatory material that favors teaching-learning and can be used to inform the elderly and caregivers, even in the absence of health professionals.

The publication of the booklet is expected by professionals, professors and health students who can use it on the teachingresearch-extension tripod and for the community in general, in order to contribute to the dissemination of information on behavioral and non-pharmacological behaviors that can improve sleep quality and impact the quality of life and health of the elderly.

\section{CONCLUSION}

The objective was achieved, since the booklet entitled "Durma bem e viva melhor" (Sleep well and live better) was built by selecting the content in the main sources about the subject, as well as addressing the demands presented by the target audience, obtained by a focus group that preceded the construction. In addition, with I-CVI higher than 0.8; S-CVI of 0.99 and Binomial Testing that confirmed a statistically greater agreement to $80 \%$, the booklet was considered valid by specialists, regarding content (objective, structure, presentation and relevance). The elderly who evaluated the booklet considered it to be comprehensive, attractive, clear and objective. Thus, although the booklet presents itself as an option of a technological resource to be used by nursing, in educational interventions, in order to contribute to the multiplication of information about sleep hygiene, it is necessary to investigate the effectiveness of the its use in improving the quality of sleep of the elderly.

\section{REFERENCES}

1. Silva KKM, Lima GAF, Gonçalves RG, Menezes RMP, Martino MMF. Sleep changes and interference in quality of life in aging. Rev Enferm UFPE [Internet]. 2017 [cited 2018 Mar 31];11(Suppl 1):422-8 Available from: https://periodicos.ufpe.br/revistas/revistaenfermagem/article/ view/11923

2. St-Onge MP, Grandner MA, Brown D, Conroy MB, Jean-Louis G, Coons M, et al. Sleep duration and quality: impact on lifestyle behaviors and cardiometabolic health: a scientific statement from the American Heart Association. Circulation [Internet]. 2016 [cited 2018 Mar 31];134(18):e367-86. Available from: https://www.ncbi.nlm.nih.gov/pubmed/27647451

3. Ribeiro NF. Tratamento da Insônia em Atenção Primária à Saúde. Rev Bras Med Fam Comunidade [Internet]. 2016 [cited 2018 Mar 31];11(38):1-14. Available from: https://www.rbmfc.org.br/rbmfc/article/view/1271/820

4. Silva KV, Rosa MLG, Jorge AJL, Leite AR, Correia DMS, Silva DS, et al. Prevalence of risk for obstructive sleep apnea syndrome and association with risk factors in primary care. Arq Bras Cardiol [Internet]. 2016 [cited 2018 Mar 31];106(6):474-80. Available from: http://www. arquivosonline.com.br/2016/10606/pdf/10606004.pdf

5. Bacelar A, Pinto Jr LR. Insônia do diagnóstico ao tratamento. III Consenso Brasileiro de Insônia. São Paulo: Omnifarma Ltda; 2013.

6. Abraham O, Pu J, Schleiden $\sqcup$, Albert SM. Factors contributing to poor satisfaction with sleep and healthcare seeking behavior in older adults. Sleep Health [Internet]. 2017 [cited 2018 Mar 31];3(1):43-8. Available form: http://www.sleephealthjournal.org/article/S2352-7218(16)30128-0/abstract

7. Sagayadevan V, Abdin E, Shafie SB, Jeyagurunathan A, Sambasivam R, Zhang Y, et al. Prevalence and correlates of sleep problems among elderly Singaporeans. Psychogeriatrics [Internet]. 2017 [cited 2018 Mar 31];17(1):43-51. Available from: https://onlinelibrary.wiley.com/doi/ full/10.1111/psyg. 12190

8. Tsapanou A, Gu Y, O'Shea DM, Yannakoulia M, Kosmidis M, Dardiotis E, et al. Sleep quality and duration in relation to memory in the elderly: initial results from the Hellenic Longitudinal Investigation of Aging and Diet. Neurob Learn Memory [Internet]. 2017 [cited 2018 Mar 31];141:217-25. Available from: https://www.sciencedirect.com/science/article/pii/S1074742716304208

9. Friedrich A, Schlarb AA. Let's talk about sleep: a systematic review of psychological interventions to improve sleep in college students. J Sleep Res [Internet]. 2018 [cited 2018 Mar 31];27(1):4-22. Available from: https://www.ncbi.nlm.nih.gov/pubmed/28618185

10. Ohayon M, Wickwire EM, Hirshkowitz M, Albert SM, Avidan A, Daly FJ, et al. National Sleep Foundation's sleep quality recommendations: first report. Sleep Health [Internet]. 2017 [cited 2018 Mar 31];3(1):6-19. Available from: http://www.sleephealthjournal.org/article/ S2352-7218(16)30130-9/pdf 
11. Parent K, Jones K, Phillips L, Stojan JN, House JB. Teaching patient and family centered care: integrating shared humanity into medical education curricula. AMA J Ethics [Internet]. 2016 [cited 2018 Mar 31];18(1):24-32. Available from: https://www.ncbi.nlm.nih.gov/ pubmed/26854633

12. Araújo SNM, Santiago RF, Barbosa CNS, Figueiredo MLF, Andrade EMLR, Nery IS. Technologies for care to elderly in health services: an integrative review. Enferm Glob [Internet]. 2017 [cited 2018 Mar 31];16(2):579-95. Available from: http://revistas.um.es/eglobal/article/ view/247241/210331

13. Ministério da Saúde (BR). Portaria $n^{\circ} 2.528$, de 19 de Outubro de 2006. Aprova a Política Nacional de Saúde da Pessoa Idosa. Portal da Saúde. 2006. Available from: http://portal.saude.gov.br/portal/arquivos/pdf/2528\%20aprova\%20a\%20politica\%20nacional\%20de\%20 saude\%20da\%20pessoa\%20idosa.pdf

14. Lopes MVO, Silva VM, Araujo TL. Methods for establishing the accuracy of clinical indicators in predicting Nursing Diagnoses. Int J Nurs Knowl [Internet]. 2012 [cited 2018 Sep 21];23134-9. Available from: http://onlinelibrary.wiley.com/doi/10.1111/j.2047-3095.2012.01213.x/ epdf

15. Born T. Cuidar melhor e evitar a violência: manual do cuidador da pessoa idosa. Born T (Org). Brasília: Secretaria Especial dos Direitos Humanos, Subsecretaria de Promoção e Defesa dos Direitos Humanos; 2008. 330 p.

16. Hoffmann T, Warrall L. Designing effective written health education materials: considerations for health professionals. Disabil Rehabil [Internet]. 2004 [cited 2018 Mar 31];26(9):1166-73. Available from: https://www.ncbi.nlm.nih.gov/pubmed/15371031

17. Rosenstock IM. Historical origins of the health belief model. Health Educ. Monogr. 1974; 2(4):328-45.

18. Leite SS, Áfio ACE, Carvalho LV, Silva JM, Almeida PC, Pagliuca LMF. Construção e validação de Instrumento de Validação de Conteúdo Educativo em Saúde. Rev Bras Enferm [Internet]. 2018 [cited 2018 Set 22];71(Suppl-4):1635-41. Available from: http://www.scielo.br/pdf/ reben/v71s4/pt_0034-7167-reben-71-s4-1635.pdf

19. Sousa CS, Turrini RNT, Poveda VB. Translation and adaptation of the instrument "suitability assessment of materials" (SAM) in to portuguese. Rev Enferm UFPE [Internet]. 2015 [cited 2018 Mar 31];9(5):7854-61. Available from: https://periodicos.ufpe.br/revistas/revistaenfermagem/ article/view/10534/11435

20. Polit $\mathrm{D}$, Beck CT. The Content Validity Index: are you sure you know what's being reported? critique and recommendations. Res Nurs Health [Internet]. 2006 [cited 2018 Mar 31];29(5):489-97. Available from: https://www.ncbi.nlm.nih.gov/pubmed/16977646

21. Mishra AK, Ruitenbeek AM, Loomans MGLC, Kort HSM. Window/door opening-mediated bedroom ventilation and its impact on sleep quality of healthy, young adults. Intern J Ind Envir Health [Internet]. 2018 [cited 2018 Mar 31];28(2):339-51. Available from: https:// onlinelibrary.wiley.com/doi/pdf/10.1111/ina.12435

22. Johansson A, Adamson A, Ejdebäck J, Edéll-Gustafsson U. Evaluation of an individualised programme to promote self-care in sleep-activity in patients with coronary artery disease: a randomised intervention study. J Clin Nurs [Internet]. 2014 [cited 2018 Mar 31];23(19-20):282234. Available from: https://www.ncbi.nlm.nih.gov/pubmed/24479893

23. Machado FS, Souza RCS, Poveda VB, Costa ALS. Non-pharmacological interventions to promote the sleep of patients after cardiac surgery: a systematic review. Rev Latino-Am Enfermagem [Internet]. 2017 [cited 2018 Mar 31];25:e2926. Available from: http://www.scielo.br/pdf/rlae/ v25/0104-1169-rlae-25-e2926.pdf

24. Ferreira SRS, Périco LAD, Dias VRGF. The complexity of the work of nurses in Primary Health Care. Rev Bras Enferm [Internet]. 2018 [cited 2018 Mar 31];71(Supl 1):784-9. Available from: http://www.scielo.br/pdf/reben/v71s1/0034-7167-reben-71-s1-0704.pdf

25. Teng NIMF, Ismail NA, Ismail NH, Ahmad T. Development and validation of an educational booklet for sunnah practices in improving quality of life. Envr Behav Proceed J [Internet]. 2017 [cited 2018 Mar 31];2(5):151-9. Available form: https://ebpj.e-iph.co.uk/index.php/ EBProceedings/article/view/692/pdf_1

26. Nascimento MHM, Teixeira E. Educational technology to mediate care of the "kangaroo family" in the neonatal unit. Rev Bras Enferm [Internet]. 2018;71(Suppl 3):1290-7. [Thematic Issue: Health of woman and child]. Available from: http://www.scielo.br/pdf/reben/ v71s3/0034-7167-reben-71-s3-1290.pdf

27. Lima ACMAC, Bezerra KC, Sousa DMN, Rocha JF, Oriá MOB. Development and validation of a booklet for prevention of vertical HIV transmission. Acta Paul Enferm [Internet]. 2017 [cited 2018 Mar 31];30(2):181-9. Available from: http://dx.doi. org/10.1590/1982-0194201700028

28. Stothard JR, Khamis AN, Khamis IS, Neo CHE, Wei I, D. Rollinson. Health education and the control of urogenital schistosomiasis: assessing the impact of the juma na kichocho comic-strip medical booklet in Zanzibar. J Biosoc Sci. 2016;48(Suppl 1):S40-55. doi: 10.1017/ S0021932016000122

29. Galindo Neto NM, Caetano JÁ, Barros LM, Silva TM, Vasconcelos EMR. First aid in schools: construction and validation of an educational booklet for teachers. Acta Paul Enferm [Internet]. 2017 [cited 2018 Mar 31];30(1):87-93. Available from: http://www.scielo.br/pdf/ape/v30n1/ en_1982-0194-ape-30-01-0087.pdf

30. Cordeiro LI, Lopes TO, Lira LEA, Feitoza SMS, Bessa MEP, Pereira MLD, et al. Validation of educational booklet for HIV/Aids prevention in older adults. Rev Bras Enferm [Internet]. 2017 [cited 2018 Mar 31];70(4):775-82. Available from: http://dx.doi.org/10.1590/0034-7167-2017-0145

31. Sabino LMM, Ferreira AMV, Mendes ERR, Joventino ES, Gubert FA, Penha JC, et al. Validation of primer for promoting maternal self-efficacy in preventing childhood diarrhea. Rev Bras Enferm [Internet]. 2018;71(Suppl 3):1412-9. [Thematic Issue: Health of woman and child]. Available from: http://www.scielo.br/pdf/reben/v71s3/0034-7167-reben-71-s3-1412.pdf 